\title{
BASAL SLIDING AND MOVEMENT NEAR THE MARGIN OF THE GLACIER ØSTERDALSISEN, NORWAY
}

\author{
By W. H. Theakstone \\ (School of Geography, Victoria University of Manchester, Manchester I3, England)
}

\begin{abstract}
Observations in and around natural caves beneath the glacier Østerdalsisen in 1961 and 1962 indicated that, within the marginal zone, basal sliding played a major part in the movement measured at the upper surface. Sliding rates apparently were influenced by the availability of water at the glacier. The contribution of differential movement within the ice, which was unimportant within the outermost part (about $10 \mathrm{~m}$.) of the glacier, increased with distance from the edge. Movement at the bottom was free from macroscopic irregularities, except where local conditions at the bed influenced the mode of flow. Air temperatures within the innermost parts of subglacial caves were almost constant, below $0^{\circ} \mathrm{C}$. Studies indicated that large gaps are unlikely to exist between the glacier and its bed when the ice is more than
\end{abstract}

RÉsumÉ. Observations directes du glissement basal et du movement près du bord du Glacier Østerdalsisen, Norvège. Des observations dans et autour des caves naturelles sous le glacier Osterdalsisen en I96 I et en I962, montrent que, dans la zone marginale, le glissement basal joue un rôle primordial dans le mouvement mesuré à la surface supérieure. Les vitesses de glissement sont apparamment influencées par l'existence d'eau dans le glacier. La contribution de mouvement différentiel dans la glace, qui était négligeable dans la partie extrême (environ Io m) du glacier, augmentait avec la distance au bord. Le mouvement au fond était libre d'irrégularités macroscopiques, excepté là où des conditions locales du lit influençaient le mode d'écoulement. Les températures de l'air dans les parties les plus internes des caves sous-glaciaires étaient presque constantes, en-dessous de $0^{\circ} \mathrm{C}$. Les recherches ont montré que de larges espaces libres ne peuvent exister entre le glacier et son lit lorsque la glace a plus de $50 \mathrm{~m}$ d'épaisseur.

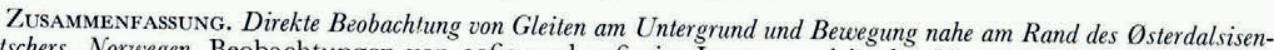
Gletschers, Norwegen. Beobachtungen von ${ }_{1961}$ und 1962 im Innern und in der Umgebung von natürlichen Höhlen unter dem Østerdalsisen-Gletscher ergaben, dass in der Randzone das Gleiten am Untergrund einen grösseren Teil der an der Oberfläche gemessenen Bewegung ausmachte. Die Gleitgeschwindiglieiten waren sichtlich durch die Verfügbarkeit von Wasser im Gletscher beeinflusst. Der Anteil der differentiellen Bewegung im Eis, der im äussersten Teil des Gletschers (ca. Io m) unbedeutend war, nahm mit dem Abstand vom Rande zu. Die Bewegung an der Sohle zeigte keine makroskopischen Unregelmässigkeiten ausser dort, wo örtliche Verhältnisse am Bett die Art des Fliessens beeinflussten. Die Lufttemperaturen in den innersten Teilen subglazialer Höhlen waren beinahe konstant und unter $0^{\circ} \mathrm{C}$. Untersuchungen zeigten, dass grössere Hohlräume zwischen dem Gletscher und seinem Bett kaum vorkommen dürften, wenn das
Eis mehr als $50 \mathrm{~m}$ dick ist.

\section{INTRODUCTION}

Natural caves beneath the outer part of the glacier Østerdalsisen (lat. $66^{\circ} 3 \mathrm{I}^{\prime} \mathrm{N}$., long. $14^{\circ} \mathrm{O} 7^{\prime}$ E.) facilitated investigation of the nature and rate of movement at the bottom in I $96 \mathrm{I}$ and I962, and of the contribution of basal sliding to surface flow. Sliding was recorded directly during a period of sixty-three days, and seasonal variations of flow within the marginal zone were measured. An attempt was made to ascertain the relation between the ice thickness and the area of contact between the glacier and its bed.

\section{Subglacial Gaves at Østerdalsisen}

Østerdalsisen is the southernmost outlet of the ice cap Svartisen in Norway (Theakstone, 1965). From an accumulation area of about $50 \mathrm{~km} .^{2}$ on a plateau I IOO-I $300 \mathrm{~m}$. above sea-level, the glacier descends to a basin north of Burfjell; its lower part is bordered to the west and north-west by Kamplien, and to the east by Svartisfjell (Fig. I). From the basin, where the surface is relatively even and unbroken at about $300 \mathrm{~m}$. above sea-level, the ice spreads out in the direction of Østerdalen, the valley to the south-west, and towards Svartisdal in the east.

In its descent from the plateau, Østerdalsisen crosses a series of steps on Svartisfjell. Resembling a gigantic staircase, these are roughly parallel, and trend obliquely across the 
line of greatest slope of the valley side. The step pattern is most marked on the lower part of Svartisfjell, where vertical or near-vertical "cliffs", $\mathrm{I} \cdot 5^{-5} \mathrm{~m}$. high, alternate with gently inclined "treads", 8-15 m. broad. Where the glacier is relatively thin, a series of gaps is left against the rock cliffs. The floor and up-glacier wall of the tunnels, or ice caves, formed in this way are of rock, and the roof and down-glacier side are made by the bottom of the glacier (Fig. 2). The caves provide comparatively easy access to the base of the glacier, and permit study of conditions there.

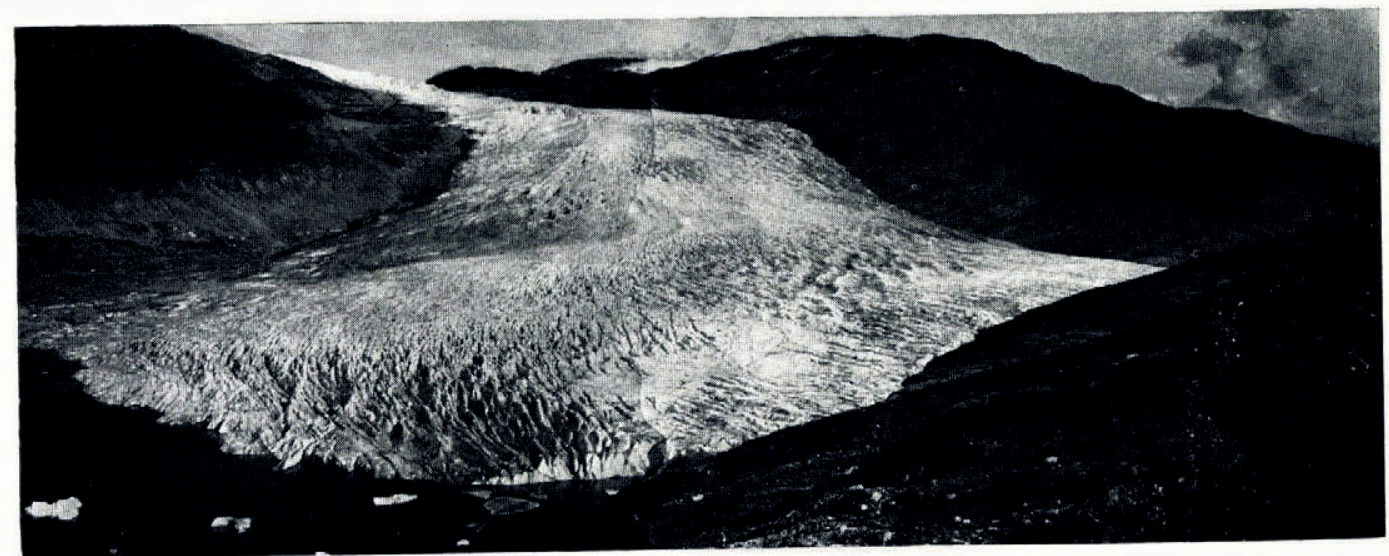

Fig. I. Osterdalsisen seen from the south-west, 24 August 1963. In the foreground are the lower slopes of Burfjell. At the right of the photograph are the rock steps of Svartisfjell, which give rise to the subglacial caves. The "main cave" studied in 1961 and 1962 was at the lower part of that section of the glacier border which appears in a near-vertical position on the photograph

\section{Observations in the Main Cave in ig6i and 1962}

Preliminary studies were carried out within the subglacial caves at Østerdalsisen in 1959 and 1960 , and detailed investigations were undertaken in the summers of 1961 and 1962 . In mid-July I96r, the main cave chosen for observations was about $75 \mathrm{~m}$. long (Fig. 3). The form of the $50 \mathrm{~m}$. long outer section was controlled by the $\mathrm{I}-3 \mathrm{~m}$. high cliff at the upglacier side. The broad middle section of the cave was rather low, and the floor descended steeply from it to the small inner section, which was associated with a different rock cliff, I-2 m. high.

The horizontal component of the movement of the ice was measured at a number of sites within the cave. A self-recording instrument, which was installed at the inner end early in the first summer, operated for about nine weeks. Unfortunately, conditions prevented direct recording of basal movement in 1962. An almost complete record of movement at the inner end of the cave was obtained for the period 7 July-7 September ig6r. The peg used remained tight in its hole; it was rigid, and proved impossible to remove from the ice at the end of the summer. Great care was taken to avoid accidental recording of jerks caused by factors other than the movement of the ice. The few accidental contacts with the instrument which resulted from the restricted space at the inner end of the cave were noted carefully.

In mid-August it became clear that the instrument peg, which had moved from the centre of the arching cave roof, would not contact the rock floor before recording had to be ended. As some record of movement at the actual contact was desired, another peg (Instrument Peg 2) was placed in a vertical section of the ice fairly close to the floor, which 
was covered by a thin layer of grit and mud. Although for some time it seemed that this second peg, too, might remain separated from the rock by a thin layer of ice, it did eventually meet the floor. In I96r, seven pegs additional to those used in conjunction with the recording instrument were employed (Fig. 3). Three of these were placed along the line of flow of the ice in the middle section of the cave indicated clearly by scoring of the glacier bottom. The shattered remains of Pegs 6 I. I and 6r.2, from the inner section, were found in the adjacent down-glacier cave on 28 July i 962 . Pegs were not used in 1962, but seven holes were drilled in the glacier bottom (Fig. 3), and measurements of their movement were undertaken. Additional holes were drilled along the lines of flow passing through four of these.

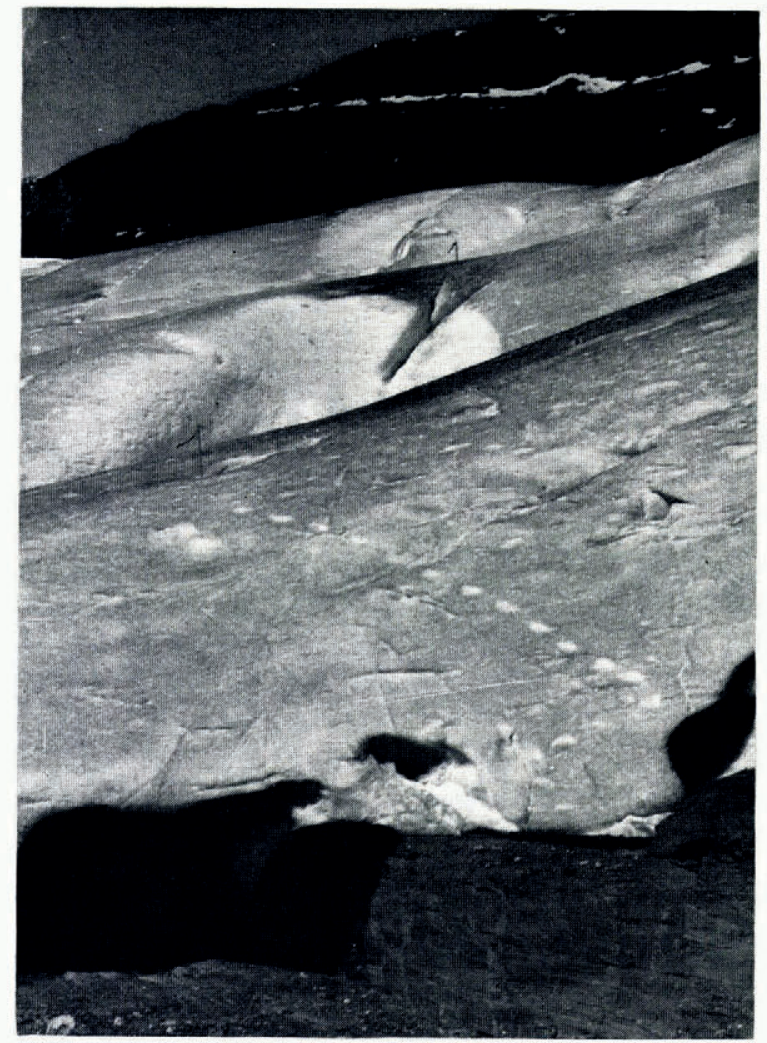

Fig. 2. The entrance to the "main cave" on Svartisfjell, 16 July 1962

\section{Results of Subglacial Observations}

Between I8 July r96r and 22 August i962, Peg 6r.2 moved I I 50 ( \pm 50 ) cm., at a mean rate of $2 \cdot 9( \pm \mathrm{O} \cdot \mathrm{I}) \mathrm{cm}$./day. With one exception the mean rates of movement determined within the main cave for various periods during the summer of I961 were within the range $4.7-7.0 \mathrm{~cm}$./day; Peg $6 \mathrm{I} .6$ moved at a mean rate of $9 \cdot 7( \pm 0 \cdot \mathrm{I}) \mathrm{cm} . /$ day between $\mathrm{I} 9$ and 29 August. In the summer of 1962 , basal velocity was within the range $4 \cdot 4-5 \cdot 4 \mathrm{~cm}$./day everywhere except at the hole very close to the margin of the glacier, which moved $5 \cdot 5^{-}$ $5.6 \mathrm{~cm}$./day between $\mathrm{I} 7$ and $28 \mathrm{July}$. (Results correct to nearest $0 . \mathrm{I} \mathrm{cm}$./day.) Direct observations at Østerdalsisen thus show that summer rates of sliding are greater than the mean annual rate. The same conclusion was reached by Elliston for the Gornergletscher on the less direct evidence of changes of surface movement ([Elliston], r962). 


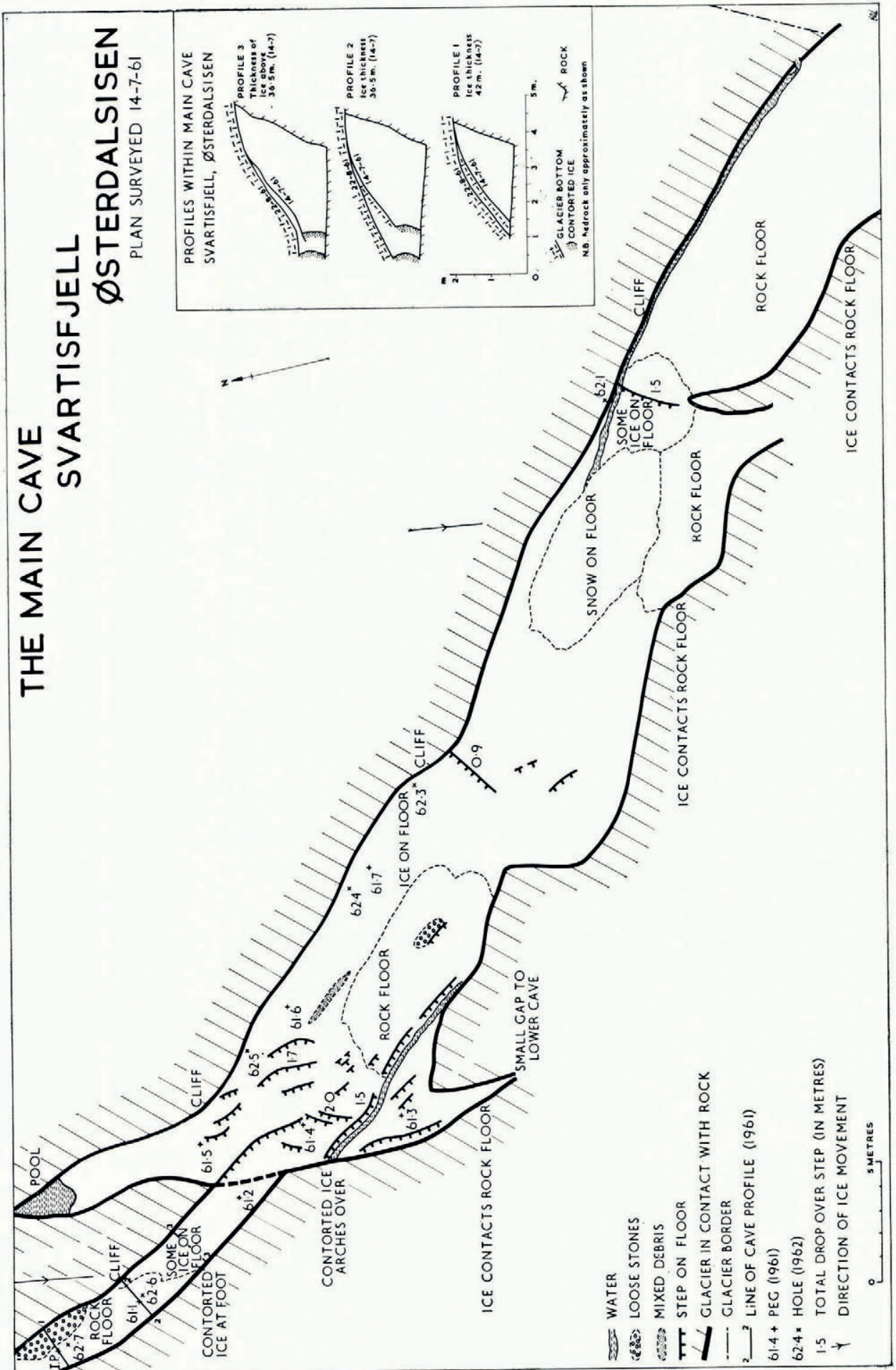

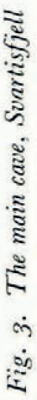


A number of the pegs used in 1961 moved more rapidly in early and mid-August than in July, and their rate of movement decreased again in late August and early September. At other pegs, however, similar variations did not occur (Fig. 4a). Throughout the cave, the direction of movement was almost uniform, towards the melting glacier margin. In I962, the movement of ice at the base of Østerdalsisen was rather less rapid and more regular than in $196 \mathrm{r}$ (Fig. 4b).

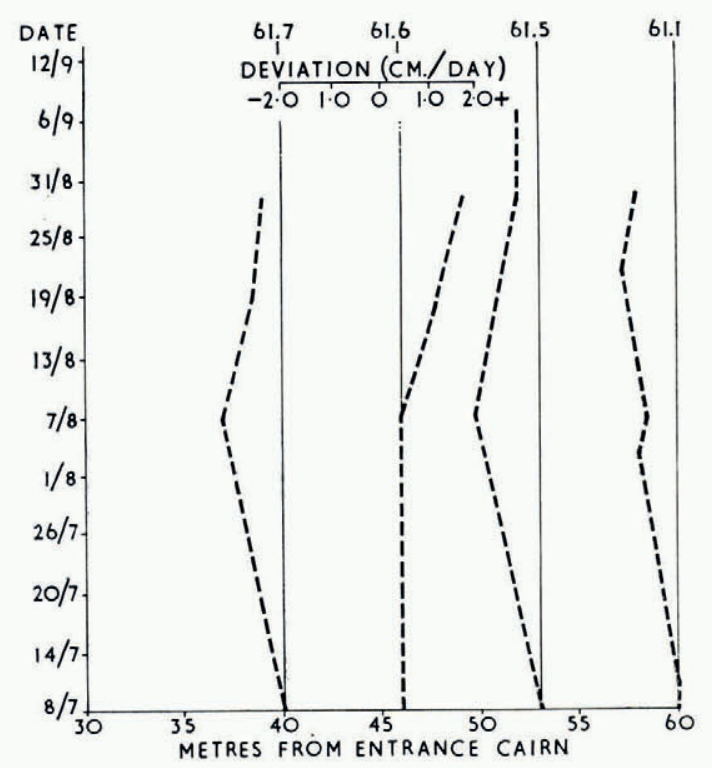

Fig. 4a. Movement of pegs in the main cave at the glacier bottom, 196I. The vertical lines represent $6 \cdot 0 \mathrm{~cm}$./day and deviations from this rate are plotted

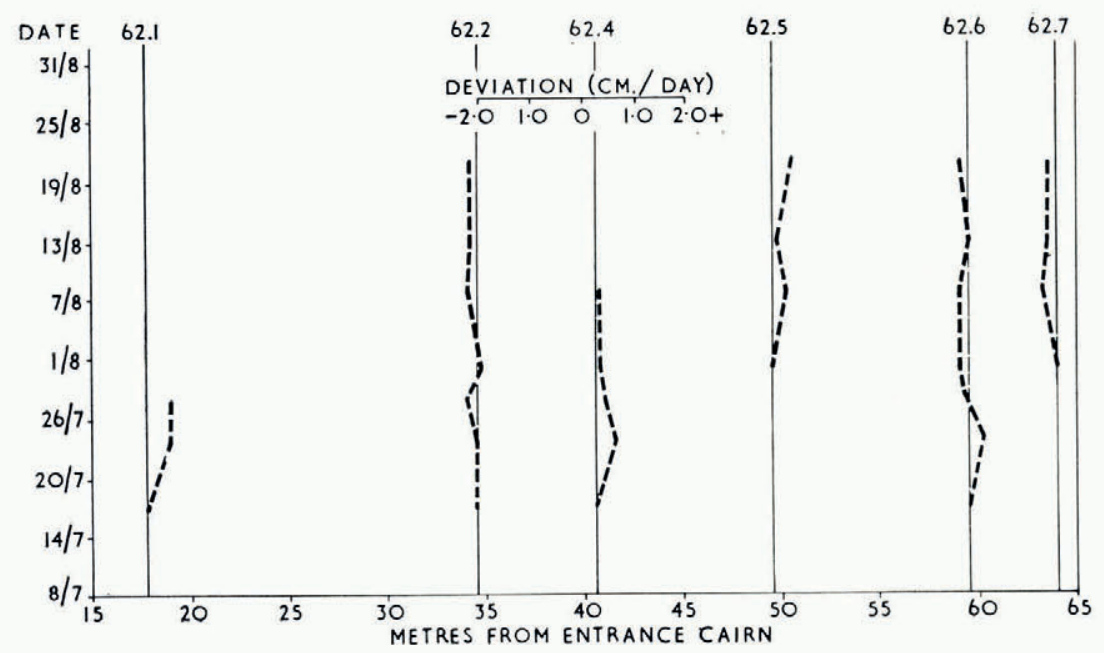

Fig. $4 b$. Movement of holes in the glacier bottom, 1962 . The vertical lines represent $5.0 \mathrm{~cm}$. /day and deviations from this rate are plotted 
The separation of pegs spaced along a line of flow in the middle section did not vary significantly during the summer: the measured distance between Pegs 6r.4 and 6r.5 was I $4 \cdot 00 \mathrm{ft}$. $(427 \cdot 7 \mathrm{~cm}$.) on I 4 July, I $3 \cdot 96 \mathrm{ft}$. $(426 \cdot 5 \mathrm{~cm}$.) on 2 I July, and $426 \mathrm{~cm}$. on 29 August, distances being correct to $\pm 0 \cdot 05 \mathrm{ft}$. ( $\pm \mathrm{I} \cdot 5 \mathrm{~cm}$.). The distance between Pegs $6 \mathrm{r} .3$ and $6 \mathrm{r} .4$ remained constant at about $407 \mathrm{~cm}$.

Measurements along lines of holes drilled across the cave roof in 1962 confirmed that, in general, little differential movement occurred along any particular line of flow of the ice (Table I). For the most part, the longitudinal strain-rates were less than 0.085 year $^{-1}$. Along line 5, however, the down-glacier end of the ice arch tended to flatten off as it approached the sloping rock floor, so that the cave roof had a double curve, concavo-convex along the line of flow. Results of measurements at this line showed a consistent trend, the overall distance between holes increasing along the convex slope near the cave floor.

\begin{tabular}{|c|c|c|c|c|}
\hline Date & 3o fuly & $3^{I}$ Fuly & I3 August & $2 I$ August \\
\hline \multicolumn{5}{|l|}{ Line 2} \\
\hline $\begin{array}{c}\mathrm{i}-\mathrm{ii} \\
\mathrm{ii}-\mathrm{iii}\end{array}$ & $\begin{array}{l}52 \\
62\end{array}$ & $\begin{array}{l}5^{2} \\
61 \cdot 5\end{array}$ & $5^{1}$ & $5 \mathrm{I}$ \\
\hline 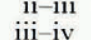 & & $6 I \cdot 5$ & $60 \cdot 5$ & $6_{2}$ \\
\hline $\begin{array}{l}\text { iii-iv } \\
\text { iv-v }\end{array}$ & $\begin{array}{l}77 \cdot 5 \\
59\end{array}$ & $77 \cdot 5$ & 78 & $\mathrm{~A}$ \\
\hline $\begin{array}{l}\text { iv-v } \\
v-v i\end{array}$ & 59 & 59 & 60 & A \\
\hline $\mathrm{v}-\mathrm{vi}$ & $47 \cdot 5$ & $47 \cdot 5$ & $4^{6 \cdot 5}$ & A \\
\hline vi-vii & $5^{6 \cdot 5}$ & $57 \cdot 5$ & & - \\
\hline \multicolumn{5}{|l|}{ Line 5} \\
\hline i-ii & - & 100 & 100 & 100 \\
\hline ii-iii & - & 118 & 119.5 & 120 \\
\hline iii-iv & - & 112 & 114.5 & 118.5 \\
\hline \multicolumn{5}{|l|}{ Line 6} \\
\hline i-ii & - & $69 \cdot 5$ & $68 \cdot 5$ & 70 \\
\hline $\mathrm{ii}-\mathrm{iii}$ & - & $5^{8}$ & $57 \cdot 5$ & $57 \cdot 5$ \\
\hline iii-iv & 一 & $57 \cdot 5$ & $5^{8}$ & 56 \\
\hline iv $-\mathrm{v}$ & - & $3^{6} \cdot 5$ & $34 \cdot 5$ & $\mathrm{C}$ \\
\hline \multicolumn{5}{|l|}{ Line 7} \\
\hline i-ii & 一 & $69 \cdot 5$ & $70 \cdot 5$ & 69 \\
\hline ii-iii & - & $71 \cdot 5$ & $72 \cdot 5$ & $7^{2}$ \\
\hline
\end{tabular}

Traces obtained with the recording instrument during the first five weeks of observations in $196 \mathrm{I}$ were fairly smooth; there were no abrupt changes of the rate of movement of the instrument peg. Instrument Peg 2 was used from 20 August, though it did not make contact with the valley floor until 2 September. From that time, the peg moved up the sloping bed, along the ice/rock contact. In contrast to earlier traces, those obtained for the period 29 August to 7 September showed a series of jerks, up to half a centimetre or more in size. Irregularities of movement of Instrument Peg 2 were more pronounced after 2 September than in the period preceding that date (Fig. 5). It was clear that movement recorded at, and a few centimetres from, the contact between the glacier bottom and the cave floor was of a jerky nature, whilst further from the contact it was smoother and more regular.

\section{Surface Movement}

The surface velocity of Østerdalsisen in the vicinity of the main cave was determined with the aid of four stakes during the summer of I96 I and of eight in I962. In both summers, the directions of movement of all the stakes were very similar, and the rate of movement increased with distance from the border (Figs. 6 and 7). However, the rate was generally 
higher in 1961 than in I962. Thus, Stake 62. I moved at a mean rate of $5.7 \mathrm{~cm}$./day, compared with the $7.6 \mathrm{~cm}$./day found for Stake $6 \mathrm{I} . \mathrm{I}$ at almost exactly the same site, $20-25 \mathrm{~m}$. from the edge of the glacier. Values at about $55 \mathrm{~m}$. were $7.6 \mathrm{~cm}$./day and $8 \cdot 4 \mathrm{~cm}$./day. The rate of sliding at the bottom of the glacier also was less rapid in 1962 : about $50 \mathrm{~m}$. from the edge it was only $4.8 \mathrm{~cm}$./day, compared with about $5.6 \mathrm{~cm}$./day in $196 \mathrm{I}$.
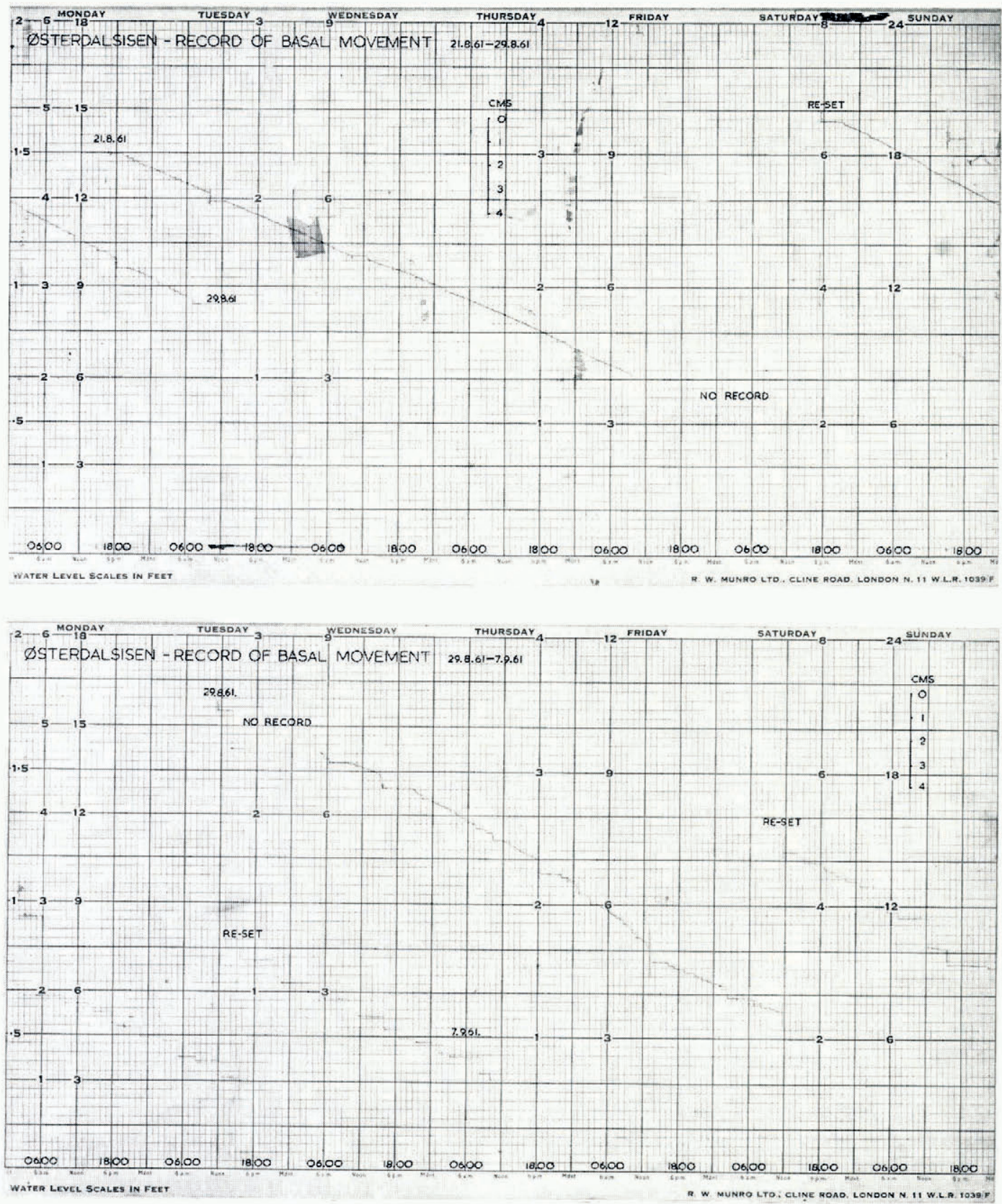

Fig. 5. Records of basal movement, Instrument Peg 2, Osterdalsisen, $196 \mathrm{I}$ 
The outermost part of the glacier, which hardly made contact with the rock below, moved as a rigid block. Differential motion between the upper and lower surfaces only became significant about 8 or $9 \mathrm{~m}$. from the edge, as the ice thickness and the proportion of the glacier bottom in contact with the bed increased (Fig. 7). In both I961 and I962, basal velocity was responsible for about two-thirds of the movement observed at the surface of the glacier even where ninety per cent of the bottom was in contact with the bed, about $50 \mathrm{~m}$. from the margin. In both years, the surface velocity $75 \mathrm{~m}$. from the edge of the glacier was only about fifty per cent greater than that at the border. In 1962 movement at the side was twenty-five per cent of that $300 \mathrm{~m}$. away. Clearly, surface movement near the margin of this glacier is due primarily to basal sliding.

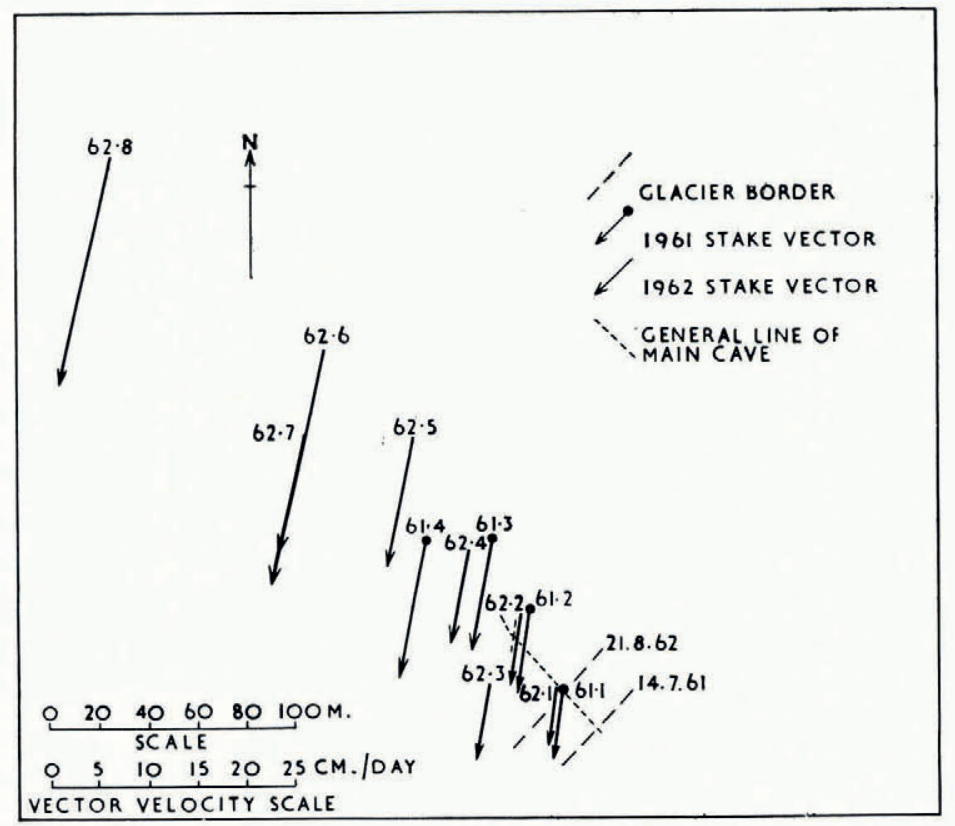

Fig. 6. Movement of cave area surface stakes, 1961 and 1962

\section{Changes of Cave Profiles}

Towards the end of the summer of 1960 , it was found that caves beneath Østerdalsisen could be followed to greater distances, and that parts formerly impassable because of the low height of the roof were no longer the limit of possible progress. The height of the rock cliff, and the relation between its orientation and the direction of ice movement, had a significant effect upon the size and length of a cave. Melting had no importance in the development or maintenance of profiles within the inner part. In $196 \mathrm{I}$, profiles were measured across the main cave on Svartisfjell at $10 \mathrm{ft}$. $(3 \mathrm{~m}$.) intervals on at least two occasions. Changes were found to occur at all parts of the cave; although considerable in the outer section, they were relatively slight in the inner section. A continuous record of air temperature at the inner end of the cave about $65 \mathrm{~m}$. from the entrance and $22 \mathrm{~m}$. below its level was obtained with a screened thermograph for the period I2 August-4 September, and regular check readings were taken with an alcohol thermometer. The temperature remained almost constant at $-\mathrm{I} \cdot \mathrm{O}^{\circ} \mathrm{C}$. Although slight rises did occur, the temperature 


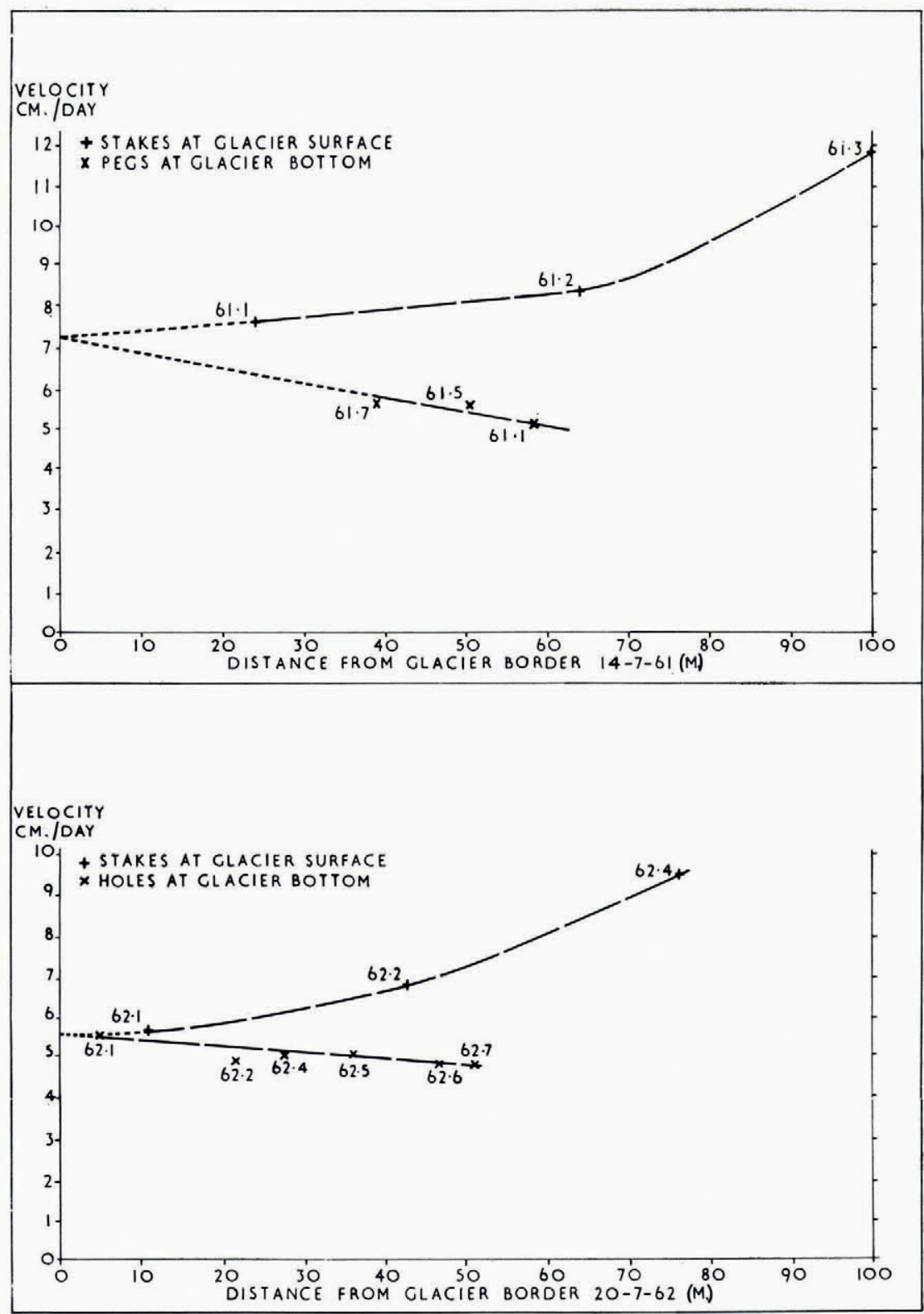

Fig. 7. Relation of basal and surface movement, 1961 and 1962

only reached $0^{\circ} \mathrm{C}$. during periods of wet weather, when the amount of water entering the Svartisfjell caves from the valley side increased considerably. Circulation of warm air within the cave was restricted to the outer and middle sections where, in contrast with the inner section, cave profiles were affected by melting of the ice. Unfortunately, ice and rock temperatures could not be determined, since suitable instruments were not available at the time. 
Three profiles were measured within the inner section of the cave, along lines normal to the face of the rock cliff (Fig. 3). Contorted ice intervened between the rock floor and the active glacier bottom at Profiles 2 and 3. The contorted ice resulted from spiralling of the bottom part of the glacier, which rotated as it impinged obliquely upon the sloping rock floor (Theakstone, I966). The thickness of the ice above the sites on 14 July ranged from about $38 \mathrm{~m}$. above Profile 3 to $42 \mathrm{~m}$. above Profile I. Between I 4 July and 22 August the ice thickness decreased by about $2 \mathrm{~m}$. above all three profiles.

Examination of the relation between the thickness of the overlying ice and the radius of curvature of ice cave profiles suggested that the radius was inversely proportional to a fairly high power $(8-10)$ of the thickness (Table II). The different flow conditions in the

\begin{tabular}{|c|c|c|c|}
\hline Date & Profile & $\begin{array}{c}\text { Thickness of } \\
\text { overlying ice } \\
\mathrm{m} .\end{array}$ & $\begin{array}{c}\text { Radius of } \\
\text { curvature } \\
\mathrm{m} .\end{array}$ \\
\hline I4 July I96I & I & 42 & $4 \cdot 0$ \\
\hline 22 August ig6I & I & 40 & $4 \cdot I$ \\
\hline 14 July i 96 I & 2 & $3^{6 \cdot 5}$ & $3 \cdot 9$ \\
\hline 22 August 1961 & 2 & 35 & $5 \cdot 2$ \\
\hline 14 July 196i & 3 & $3^{6 \cdot 5}$ & $4 \cdot 2$ \\
\hline 22 August I96I & 3 & 35 & $5 \cdot 4$ \\
\hline I4 July I96I & 4 & 29 & $43 \cdot 5$ \\
\hline I4 July I96I & 5 & 20 & $34 \cdot 5$ \\
\hline
\end{tabular}

outer part of the glacier, which tended to move more-or-less as a solid block, and the considerably higher value there of the proportion of the glacier not in contact with the bed, caused a breakdown of the relation for ice thicknesses less than about $25 \mathrm{~m}$. Around the main cave, the load of the glacier on its bed, calculated from the basal contact-area ratio and the ice thickness on 23 July I 962 (Table III), was almost constant at about $3.8 \mathrm{~kg} . / \mathrm{cm} .{ }^{2}$, except below the outermost io $\mathrm{m}$. of the glacier, where the load was about $5 \cdot 4 \mathrm{~kg} . / \mathrm{cm} .^{2}$.

Table III. Basal Contact Ratio and Ice Thickness

Distance from
glacier border
$\mathrm{m}$.
$\mathrm{O}-10$
$10-20$
$20-30$
$30-40$
$40-50$
$>50$

\begin{tabular}{c} 
Area of bed \\
\hline Area of ice in contact with bed \\
\\
5 \\
$2 \cdot 1$ \\
$1 \cdot 6$ \\
$1 \cdot 4$ \\
$1 \cdot 2$ \\
I
\end{tabular}

Approx. thickness
of ice
m.
I2
20
26
30
36
42

\section{Discussion}

The surface movement of ice in the marginal zone of Østerdalsisen was less rapid in I962 than in r96r. Surface movement was largely controlled by basal sliding, and it seems that a major part of the decrease of surface velocity resulted from a decrease of basal sliding velocity.

Throughout the $60-70 \mathrm{~m}$. wide marginal zone, basal sliding in the summers of $\mathrm{rg} 6 \mathrm{I}$ and I 962 was equal to $5^{\circ}$ per cent or more of the movement of ice at the surface. The summer rates of sliding exceeded the mean annual velocity, and sliding was more rapid in the summer in which rainfall was more abundant and more frequent (Fig. 8). Comparison of the daily precipitation and the slight variations of daily rates of sliding in $196 \mathrm{I}$, extracted from the recording instrument charts, indicates a tendency for faster sliding to have occurred during 

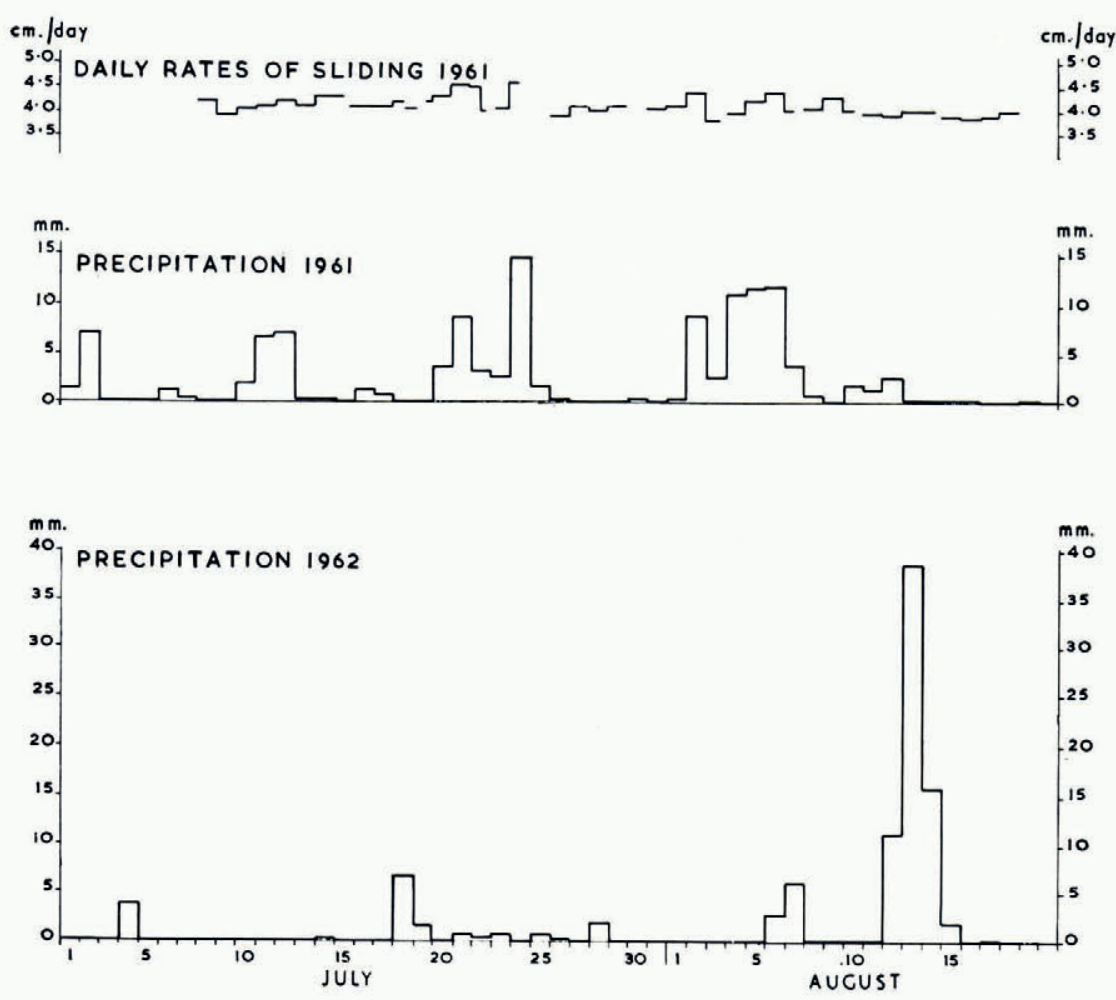

Fig. 8. Precipitation and basal sliding

wetter periods. However, water supplied to the bed of the glacier as a result of ablation at the surface, and within the outer part of the cave, may either increase or replace the effect of precipitation at different times; total ablation at the glacier surface was larger in the summer of 1962 than in that of $196 \mathrm{r}$. No direct simple relation can be identified between the amount of precipitation and the rates of sliding at the sites studied, but it is clear that the availability of water at the glacier exerts some influence on the sliding velocity, as shown by the mean daily rates of sliding in Figure 8 , and by seasonal differences between summer and winter, indicated by the mean annual rate of sliding.

On occasion, water was seen to trickle down behind the smooth, hard ice which coated the faces of rock cliffs beneath the glacier, even where the air temperature remained at $-\mathrm{I}^{\circ} \mathrm{C}$. for long periods; this carried away only very fine material from the bed. No detailed studies of the material or of its abundance at different times were undertaken. Whilst they were being washed away, or when they were totally immersed in water, the very small particles could offer little resistance to the sliding of the glacier. If they held back the glacier when conditions were relatively dry, an increase of sliding velocity would be expected to coincide with their removal. Weertman ( 1964 ) considered that a water layer only $0.35 \mathrm{~mm}$. thick might have a significant effect upon the sliding velocity of a glacier, and such an effect may explain the observations at Østerdalsisen.

At the site where it was recorded, sliding generally was regular and free of macroscopic jerks, but irregular motion was characteristic at, and very close to, the floor. That jerks were recorded before the peg contacted the floor indicates that they were a feature of the movement of the ice itself, and were not caused solely by movement of the wooden peg over 
either the rock floor or the intervening thin layer of grit and mud. Nevertheless, the presence of the fine debris is likely to have had some influence upon the nature of movement recorded near the bed. The fact that the ice descended to a floor which sloped slightly upwards across the line of flow may have been responsible to some degree for the nature of the movement. Jerks were smoothed out within a few centimetres of the floor, and it seems that the irregularity recorded at the bed was a local factor, with a local cause, related to the nature of the floor or rock wall at the site chosen for recording. It is possible that jerkiness resulted from "stick and slip" motion of the basal ice, "sticking" being caused either by jamming against material at the bed or by deformation of the ice close to the inclined floor. "Slipping" would result either as the ice in contact with obstacles at the bed melted under the influence of increased pressure, or as the basal ice was pulled along by the steady forward movement of that above it.

\section{Conclusions}

I. Basal sliding is responsible for at least one half of the flow observed at the surface within the marginal zone of Østerdalsisen. Variations of sliding rates are reflected in variations of rates of surface movement.

2. Variations of sliding velocity occur seasonally, as well as from one year to another. The velocity of sliding is related to the availability of water at the glacier.

3. Sliding within a marginal zone about $10 \mathrm{~m}$. wide is influenced by the detachment of the glacier from its bed, and the ice moves as a more-or-less rigid block. Further from the valley side, flow conditions are not the same, and differential movement within the ice is more important.

4. Jerky movement occurs at and very close to the floor, but movement a little further from the rock is macroscopically smooth and regular.

5. Little differential movement can be detected along lines of flow at the glacier bottom, but variations of the form of the ice arch may result in departures from the general pattern.

6. Fluctuations of air temperature within the outer parts of subglacial caves influence the forms of profiles there, whereas they very rarely occur at the inner, lower parts of the caves.

7. It is unlikely that there are large gaps below more than about $50 \mathrm{~m}$. of ice at Østerdalsisen.

\section{Acknowledgements}

The work reported here was carried out whilst the author was in receipt of a D.S.I.R. Studentship. The Cambridge Expeditions to Svartisen, during which the field work was undertaken, received financial support from the Royal Geographical Society, the Mount Everest Foundation and the Tennant Fund. Several members of the expeditions provided valuable assistance with the measurements made below Osterdalsisen. The author is particularly grateful for the benefit of many helpful discussions and much advice given by Dr. G. de Q. Robin. Miss E. A. Lowcock drew the figures.

MS. received 9 June 1966 and in revised form 3 April 1967

\section{REFERENGES}

[Elliston, G. R.] 1962. Seasonal changes of speed in temperate valley glaciers. Fournal of Glaciology, Vol. 4, No. 33, p. 289. [Abstract.]

Theakstone, W. H. 1965 . Recent changes in the glaciers of Svartisen. Fournal of Glaciology, Vol. 5, No. 40,

p. $4^{\mathrm{I}} \mathrm{I}-3 \mathrm{I}$.
Theakstone, W. H. 1966. Deformed ice at the bottom of Østerdalsisen, Norway. Journal of Glaciology, Vol. 6, No. 43 , p. 19-21.

Weertman, J. 1964. The theory of glacier sliding. Fournal of Glaciology, Vol. 5, No. 39, p. 287-303. 